\title{
Science, politics, and the economy: the unintended consequences of a diabolic paradox (editorial)
}

The year 2014 marked the 300th anniversary of the publication of Bernard Mandeville's Fable of the bees, or private vices, publick benefits. To celebrate this occasion, as well as its own centennial, the Erasmus University Rotterdam organized an international conference on the work of Mandeville, its historical and intellectual context, and its present relevance, on June 6,2014 . The conference was organized around three keynote lectures, ${ }^{1}$ which discussed a different field Mandeville worked on or influenced: science and medicine, moral and political philosophy, and political economy. Papers presented at the conference ranged thematically from the co-evolution of commerce, medicine and moral philosophy in the Dutch Republic, via Mandeville's attitudes to religion to the social and intellectual context of his analysis of the passions.

This special issue on Mandeville presents a selection of the twentytwo papers presented at the conference. The papers have been selected both for their quality and for their thematic diversity. They thus indicate the range of conference themes as well as the multifaceted nature of current Mandeville scholarship. All papers went through the normal process of blind review before being accepted for publication by this journal.

Mandeville was born to a family of city physicians in Rotterdam in 1670 , in an age when science, politics and commerce were rapidly changing in their methods and substance. These revolutions forced men of science and letters to reflect anew on the nature of economy, state and society. Mandeville was undoubtedly one of the most radical of these thinkers, proposing controversial new ideas about human motivation, the relationship between individual behavior and the

\footnotetext{
${ }^{1}$ These keynotes were delivered by the historian of medicine Harold Cook (Brown), known for his acclaimed Matters of exchange: commerce, medicine, and science in the Dutch golden age (2007), philosopher Margaret Schabas (University of British Columbia), author of The natural origins of economics (2005), and historian of economics Neil De Marchi (Duke), known for his innovative work on art markets in the Dutch Republic.
} 
common good, and the role of the state in society. Politically, the Mandeville family were affiliated with the States Party, which favoured economic, political, and religious liberty, as opposed to the Orangists and the allied conservative Calvinists. In the aftermath of the so-called Costerman riots in October 1690, the family was banned from Rotterdam. Bernard Mandeville, who had been educated in medicine at Leiden, ended up in England where he started publishing pasquils and pamphlets, while practicing as a physician.

The famous Fable of the bees elaborated one of these pasquils, the poem The grumbling hive, or knaves turn'd honest (1705). Published in 1714 (shortly after Lord Shaftesbury's Characteristics of man, manners, and morals [1711]), the Fable could not have been more at odds with Shaftesbury's claim that mankind's virtues automatically align with the common good. Mandeville promised to unveil man's true nature by observing the "trifling films and little pipes" of the human frame (Mandeville 1988, vol. I, 3). He claimed, provocatively, that it was human wickedness from which social benefits were to be expected. Luxury, though a private vice, contributes to a nation's prosperity; frugality leads to public ruin. Mandeville published several other increasingly philosophical works, the most important being the second volume of the Fable (1729), which substantially altered its earlier message, and An enquiry into the origin of honour, and the usefulness of Christianity in war (1732).

After the Fable was condemned in 1724 by the Grand Jury of Middlesex for its "diabolic attempts against religion", Mandeville's notoriety increased sharply. His shocking paradox that mankind's vices contributed to the common good has haunted moral philosophers, social scientists and economists ever since. In a famous lecture on the Dutch philosopher, Friedrich Hayek wrote that Mandeville, in his efforts to understand modern commercial society, was "asking the right questions" (1967, 127). But as Hayek's political antagonist the Cambridge economist Joan Robinson noted, the main question "has never been properly answered" $(1962,19)$. The papers in this collection reveal that Mandeville's lasting importance cannot be reduced to what Hayek considered his most important insight: that the unintended consequences of self-interested human actions can be mutually beneficial.

In the two opening contributions, Harold Cook and Rudi Verburg invite us to reconsider the medical, social, and political background of 
Mandeville's work. Their papers re-examine the medical and political context of Mandeville's writing. Drawing on Mandeville's personal experiences in Rotterdam and London, Cook develops a new interpretation of the links between Mandeville's most important medical tract, the Treatise of the hypochondriack and hysterick passions of 1711, and the Fable. In England Mandeville became acquainted with an intriguing group of medical innovators who opposed the opening-up of contacts between the London medical establishment and the rapidly expanding London publishing press. These acquaintances and the sting brought to his family by its banishment from Rotterdam, Cook argues, help explain Mandeville's views of politicians and medical doctors as "high-flying hypocrites".

Cook uses Mandeville's biographical trajectory to re-examine Jacob Viner's thesis about the importance of the "skilful politician" in Mandeville's political economy. Not incidentally, Hayek (1967) saw in the Fable a "talking cure": a therapy not unlike the one Mandeville developed in his Treatise on hypochondria. Just as a physician cannot contravene the human passions, so a politician can and should set up incentives aligning the passions with the common good. What the various passions are and how they are structurally related thus became a matter of great scientific as well as political concern.

As Mauro Simonazzi shows in detail, such an examination acquired great urgency for Mandeville. In the second volume of the Fable, as well as in the Enquiry into the origin of honour (1732), Mandeville distinguished with increasing clarity between self-love and self-liking, a distinction discussed in many of the other contributions to this volume as well. Mandeville linked the distinction to self-preservation and overestimation of one's own worth. Self-liking, rudimentary present in Mandeville's earlier short writings according to Cook, transforms in the later works to the driving force of what Kant so pointedly labelled man's "unsocial sociability" (Kant 1968, 37-38). Mandeville's elaboration upon the meaning of self-liking brought him closer to the distinction between the 'violent' and 'calm' passions. This distinction, Albert Hirschman (1977, 63-70) duly pointed out, was of great importance to the Scottish enlightenment's philosophy of mind. Simonazzi stresses the influence of Mandeville's Treatise on Scottish medical discourse, especially through the work of Robert Whytt, president of the Royal College of Physicians at Edinburgh in the mid-eighteenth century. 
While Cook and Simonazzi's contributions move us forward in time and invite us to rethink the relation between Mandeville's writings on medicine and moral and political philosophy, Rudi Verburg reverses the historical direction with his detailed examination of the political background of Mandeville in the Dutch Republic. While some of the best scholarship over the past decades (including E.G. Hundert's 1994 monograph) displays awareness of the influence of the political writings of the brothers De la Court, the general tendency has been to highlight Mandeville's indebtedness to the French Augustinian tradition and in particular to the Jansenists. Verburg does not deny the latter's wellestablished influence, but emphasizes how the commercial republicanism of the De la Courts and other Dutch thinkers also influenced Mandeville's central thesis: that selfish passions may lead to positive outcomes for the commonwealth (Weststeijn 2012). Unlike the De la Courts, Mandeville did not seek to align the individual and the common good; he deemed this an idea only "silly people" could maintain (Mandeville 1953, 45n1). Instead, Mandeville explored how individuals could be nudged to act for the common good by the "cunning Management" of "dextrous politicians". He thus anticipated recent interventions of behavioural economists in the policy domain. ${ }^{2}$ The common link between the De la Courts and Mandeville is, in Verburg's view, the idea that human beings, unsociable by nature, have to be made fit for society: they should be turned into "Disciplin'd Creature[s]" (Mandeville 1988, vol. I, 347).

The two articles written by Francesca Pongiglione and Mikko Tolonen, and by Renee Prendergast, suggest what this process of disciplining might look like. Their conclusions are mixed and somewhat contradictory. Pongiglione and Tolonen's careful examination of Mandeville's essay on charity schools reveals that Mandeville overstretched his arguments when unmasking the selfish motives behind charity. They read Mandeville as arguing, rather unconvincingly, that a general education would be wasted on the poor. All education does is instill false hopes for a betterment of their condition unlikely to eventuate. According to Pongiglione and Tolonen, Mandeville's reasoning leads him to make an almost categorical distinction between rich and poor, turning the latter almost into creatures of another race.

\footnotetext{
${ }^{2}$ Though for different reasons. See the recent literature sparked by Richard Thaler and Cass Sunstein's (2008).
} 
This position is, however, at odds with his commitment to the universal nature of man developed elsewhere in his writings.

Prendergast proffers a more benign reading of the same essay on charity schools. She reads the essay in light of the scholarly literature on Mandeville's stance of what came to be referred to as laissez-faire (with Jacob Viner and Friedrich Hayek taking opposing sides). Prendergast argues that Mandeville seems to have followed the "new liberal spirit" of the seventeenth century: any market transactions in which both parties benefited from the exchange were regarded as just. In this context, Mandeville's argument against the education at charity schools should be seen not as an argument against education of the poor per se, but against education that would fail to benefit the poor in the marketplace. Seen from this perspective, Mandeville did not conceive of the poor as categorically different by nature, but only by training; division of labour assigned the poor and the rich to different ranks. Mandeville considered the back-breaking toil of the poor inevitable and relief from need a blessing.

Pongiglione and Tolonen note that it is difficult, if not impossible, to find a coherent position on poverty in Mandeville's works. The lack of coherency may be explained more generally as follows. As already noted by Hayek, the generally hostile reception of the Fable induced Mandeville to search for increasingly philosophical argumentsarguments that don't always chime with his earlier, brusque pronouncements. Moreover, Mandeville employed different genres of writing that don't always easily fit together. When the Grand jury of Middlesex committed the second edition of the Fable to the flames, this was primarily because of his acerbic criticism of charity and charity schools added to the second edition, rather than because of the Fable itself-prior to this it had received a modest, but not hostile, welcome in the periodical press.

The sixth and final article by Matteo Revolti examines how the same periodical press-which had helped him to publish initially-took the opportunity to use Mandeville's ambiguous mixture of genres against him after the Grand jury's indictment. Mandeville was portrayed as an unrepentant supporter of the Whigs, as an atheist, and as a corruptor of morals. In the press, Mandeville's work came to serve as a stand-in for party political conflicts and purposes that were only marginal to his own agenda, if at all. A more engaged and honest reception of his work was found primarily in France and Scotland, well beyond the political 
turmoil of the London based Tories and Whigs. However, by concentrating on the Fable, part I, this later reception obscured the intricate relations between Mandeville's medical and socio-political works, and overlooked his fine-grained analysis of the human passions, particularly the distinction between self-love and self-liking, developed in his subsequent more philosophical works. These latter works developed ideas in ways not dissimilar to those of Scottish literati like David Hume and Adam Smith, and less dissimilar, perhaps, than they themselves realized.

LAURENS VAN APELDOORN
Leiden University
HARRO MAAS
University of Lausanne
JOHAN OLSTHOORN
KU Leuven
GUEST EDITORS
<editors@ejpe.org>

\section{REFERENCES}

Cook, Harold J. 2007. Matters of exchange: commerce, medicine, and science in the Dutch golden age. New Haven: Yale University Press.

Hayek, Friedrich A. 1967. Lecture on a master mind: Dr. Bernard Mandeville. Proceedings of the British Academy, 53: 125-141.

Hirschman, Albert. 1977. The passions and the interests: political arguments for capitalism before its triumph. Princeton: Princeton University Press.

Hundert, E.G. 1994. The enlightenment's fable: Bernard Mandeville and the discovery of society. Cambridge: Cambridge University Press.

Kant, Immanuel. 1968. Idee zu einer allgemeinen Geschichte in weltbürgerlicher Absicht. In Kant-Studienausgabe, vol. 6, ed. Wilhelm Weischedel. Frankfurt aM: Suhrkamp.

Mandeville, Bernard. 1953 [1732]. A letter to Dion, ed. J. Viner. Los Angeles: Clark Memorial Library, Augustan Reprint Society Publication.

Mandeville, Bernard. 1988 [1924]. The fable of the bees: or private vices, publick benefits, 2 vols, ed. F.B. Kaye. Indianapolis: Liberty Fund.

Robinson, Joan. 1962. Economic philosophy. Chicago: Aldine Publishers.

Schabas, Margaret. 2005. The natural origins of economics. Chicago: University of Chicago Press.

Thaler, Richard H. and Cass R. Sunstein. 2008. Nudge: improving decisions about health, wealth, and happiness. New Haven: Yale University Press.

Weststeijn, Arthur. 2012. Commercial republicanism in the Dutch golden age. Leiden: Brill. 